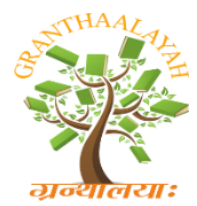

INTERNATIONAL JOURNAL OF RESEARCH GRANTHAALAYAH A knowledge Repository

Science

\title{
THE EFFECT OF SERVICE QUALITY ON CONSUMER SATISFACTION OF PALM SUGAR IN WEST JAVA
}

\author{
Nurjaya ${ }^{* 1}$ \\ ${ }^{* 1}$ Faculty of Applied Science, Universitas Suryakancana, Indonesia
}

\begin{abstract}
This study aims to explain and determine the effect of service quality on consumer satisfaction together or partially on customer satisfaction Palm Sugar in West Java. The independent variables used in this study are Physical Evidence, Reliability, Responsiveness, Assurance, and Empathy and the dependent variable in this study is consumer satisfaction. This research was conducted in West Java. The sample population used is palm sugar consumers. The sampling technique uses purposive sampling. The sample used in this study amounted to 100 respondents. Based on the results of the F Test in this study showed sig. F $0,000<0.05$ which means that Service Quality consisting of physical evidence, reliability, responsiveness, assurance and empathy together have a significant effect on customer satisfaction. Based on the results of the $t$ test, it can be seen that the variables of physical service, reliability, responsiveness and empathy partially have a significant effect on customer satisfaction. $\mathrm{T}$ test results also indicate that the Responsiveness variable (X3) has the strongest influence compared to other variables, the Responsibility variable (X3) has a dominant influence on consumer satisfaction.
\end{abstract}

Keywords: Tangible; Reliability; Responsiveness; Assurance; Empathy and Customer Satisfaction.

Cite This Article: Nurjaya. (2019). "THE EFFECT OF SERVICE QUALITY ON CONSUMER SATISFACTION OF PALM SUGAR IN WEST JAVA." International Journal of Research - Granthaalayah, 7(12), 231-238. https://doi.org/10.29121/granthaalayah.v7.i12.2019.316.

\section{Introduction}

Indonesia is an agrarian country that has a great variety of high-value agricultural products. One of them, from the palm-palman family. Like, coconut, nifah, palm, areca nut and sugar cane. Where it has a high enough glucose content that is beneficial in terms of meeting human consumption needs as a food sweetener.

Palm trees have high economic potential because almost all parts can provide financial benefits. The fruit can be made and fro favored by the people of Indonesia in general. The leaves can be used as crafts and can also be used as a roof, while the roots can be used as medicine. From the stems can be obtained fibers and sticks that have economic value. In addition, young sags can be 
sagunya, while in old age can be used as furniture. But of all the palm products, palm sap that comes from the male flower arm as an ingredient for the production of palm sugar is the greatest economic value.

West Java Province BPS data shows the economic potential in the plantation sector is quite good. This can be seen from the West Java province's GRDP showing the average growth in the Agriculture, Forestry and Fisheries sectors from 2010 to 2016 of 8.75\%.

If further observed the plantation sector, especially palm sugar products only contributed $0.47 \%$ to the West Java Province GRDP. This is relatively small considering the high potential of sugar palm in West Java. Palm Sugar GRDP from 2010 to 2016 can be seen in the following figure:

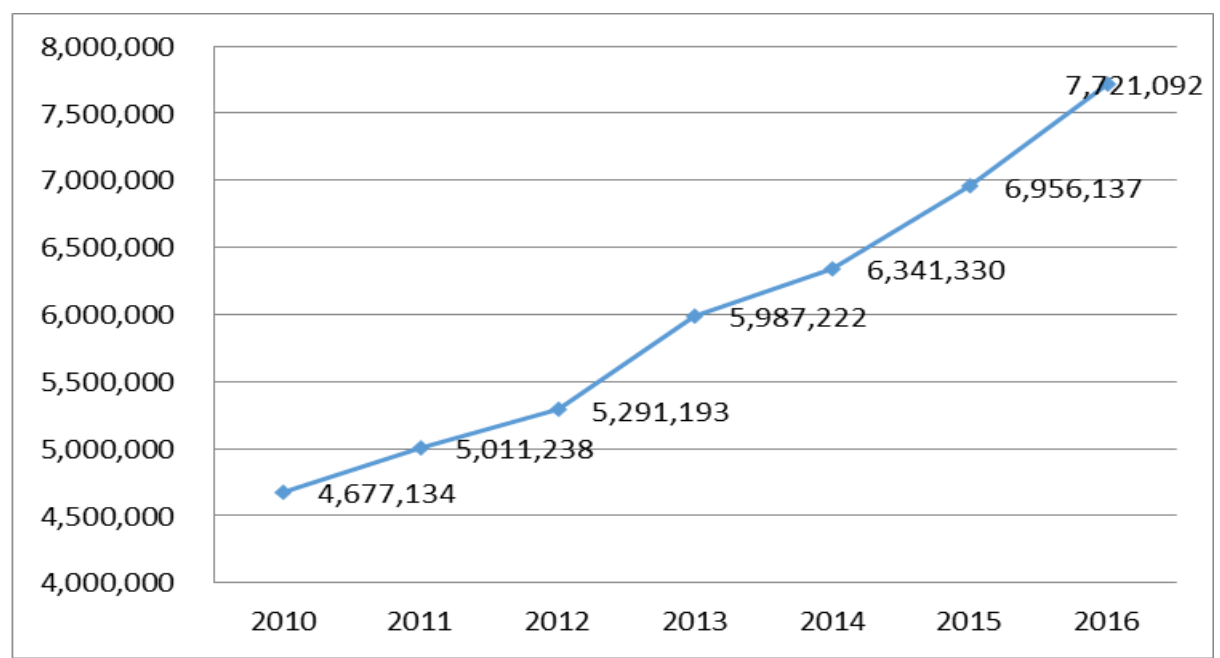

Figure 1: GRDP Palm Sugar Product in West Java Province 2016 (in Million Rupiah) Source: West Java BPS, 2018

The increasing GRDP of palm sugar is caused by the increasing area of palm sugar production. The area of palm sugar plantations in West Java is 14,204 hectares with a production of 22,489 tons in the form of brown sugar. The following are the six largest sugar-producing provinces in Indonesia.

Table 1: The Big Six Palm Producing Provinces in Indonesia in 2015

\begin{tabular}{|l|c|c|}
\hline Region & Area (Ha) & Production (ton) \\
\hline West Java* & 14.204 & 22.489 \\
\hline North Sulawesi & 6.328 & 6.889 \\
\hline North Sumatera & 5.255 & 4.352 \\
\hline South Sulawesi & 5.250 & 4.605 \\
\hline Center Java & 3.583 & 3.554 \\
\hline Bengkulu & 4.608 & 4.085 \\
\hline
\end{tabular}

Source: Statistics of the Plantation Service, 2015, West Java including Banten

The palm sugar business in Indonesia has promising prospects for development. This can be seen from the high demand both domestically and abroad, especially for the type of ant sugar, which is 
often difficult to fulfill, the results of an interview of a small industry in a month can get an order of 15-25 tons. The order has so far not been able to be fulfilled due to limited supply and lack of capital.

Regarding domestic demand, the biggest need for ant sugar comes from the food and drug industries which are scattered around Tangerang. Meanwhile, for the local market, the highest demand occurs during and before the fasting month of Ramadan. As for export demand, many come from Germany, Switzerland and Japan.

In Indonesia, the business of palm sugar is widely developed in mountainous regions. Based on the data in Figure 3. the area of the plant is relatively increasing from year to year so that the production of palm sugar also tends to increase.

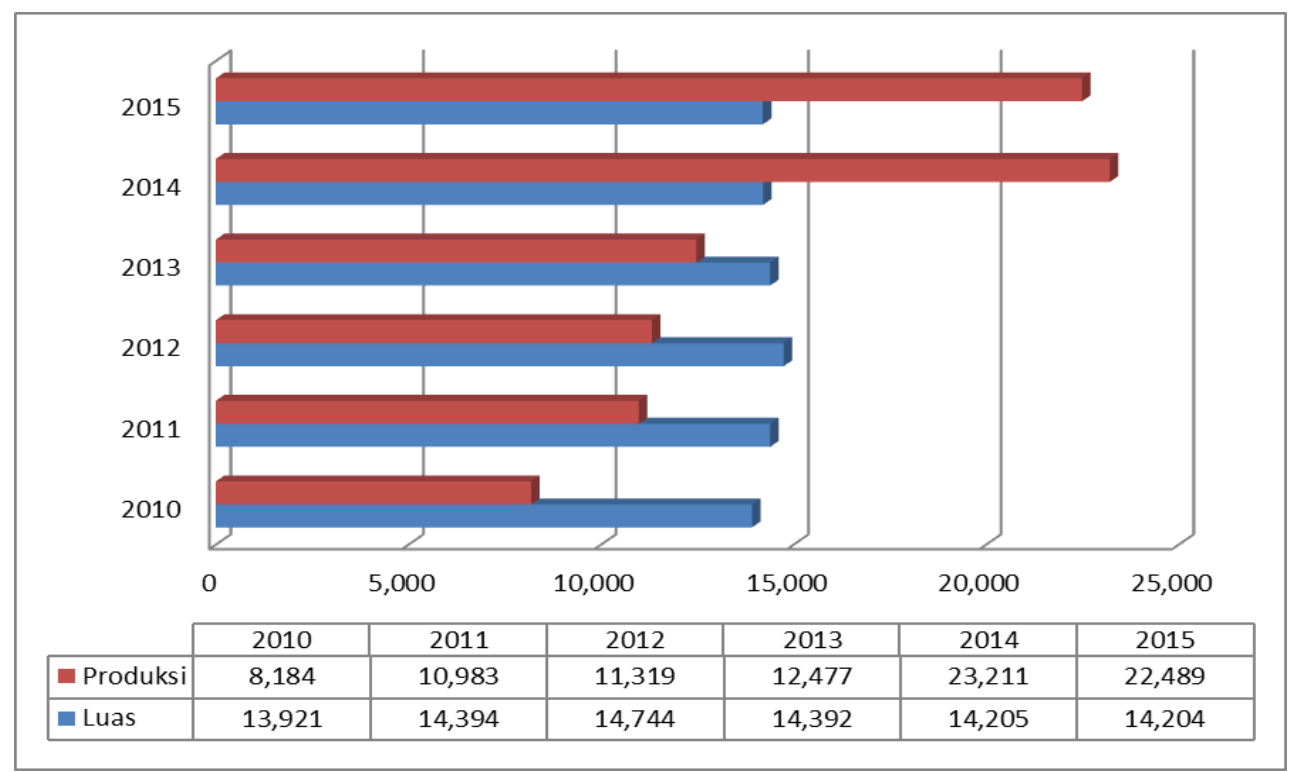

Figure 2: Development of Planted Area and Palm Sugar Production in West Java Province Source: DG of Plantation (2010-2015)

The expansion of palm sugar plantations can be indicated as a guarantee of supply of raw materials. This also means that the palm sugar business can be sustainable and has the opportunity to increase its production capacity. Sugar palm is far more productive than sugar cane in producing sugar crystals per unit area. Productivity can be 4-8 times compared to sugar cane. The yield of palm sugar is 12 percent, while the average cane is only 7 percent. Palm sugar is considered good and can be made into exportable sugar. The export price reaches IDR 50,000 / $\mathrm{kg}$ and at the consumer level it can reach IDR 90,000/ kg, while the price of cane sugar only reaches IDR7,000/ kg. DG of Agriculture, 2015).

Competition between palm sugar business in Cianjur, West Bandung, Sukabumi, Bogor, Garut and Banten Province are relatively low because there are not too many palm sugar entrepreneurs. Thus, the number of offers is still lower than the demand. Palm sugar from artisans and SME are collected by collectors at the village level. Then the sugar is brought to the district and district level collectors. From district level collectors, palm sugar products are marketed through 
wholesalers and retailers. The marketing chain is long enough so that the costs incurred are greater. This has an impact on increasing the price of palm sugar so that the price of palm sugar is affordable then the price of palm sugar from SME is suppressed. As a result, the income received is not as expected.

Marketing constraints that are still faced by entrepreneurs in marketing palm sugar products, among others: Lack of access to market information, especially regarding prices, so that craftsmen are very dependent on the price given by collectors (low bargaining position of artisans). generally craftsmen are still oriented to the needs of the family (subsystem) and not yet market oriented (market oriented). Sugar palm agroindustry is generally managed by the local community traditionally as a home scale industry. The marketing of palm sugar production is generally still limited in traditional markets. The public is still less familiar with ant palm sugar products as a substitute for cane sugar. This causes palm sugar better known for industrial needs rather than for consumption. In fact, the market opportunity to meet the needs of sweeteners in the consumption market is relatively large. One of the main factors might be the aspect of service quality so that it can make consumers feel satisfied in consuming palm sugar.

According to Supranto [1] service quality is something that service providers must do well. Quality of service as perceived by consumers, comes from a comparison between what is offered by a service company that is expectations and with their perceptions about the performance of service providers. According to Tjiptono [2] there are 5 dimensions of service quality, namely: Tangible, Reliability, Responsiveness, Assurance, Empathy. 5 dimensions will lead to perceptions about the quality of services in a company.

Consumer satisfaction is a situation that is shown by consumers when they realize that their needs and desires are as expected and well fulfilled [3]. Meanwhile, according to Kotler and Keller [4], satisfaction is a feeling of pleasure or disappointment someone who appears after comparing the performance (or results) of the product thought to the expected performance (or results). If performance fails to meet expectations, consumers will not be satisfied. If the performance is in line with expectations, consumers will be satisfied. If performance exceeds expectations, consumers will feel very satisfied.

\section{Theory}

\section{Service Quality}

The concept of service quality is the focus of assessment that reflects consumers' perceptions of the five physical dimensions and service performance, Zeithaml, Bitner and Gremler [5], revealed that there are five dimensions used to measure service quality, namely:

1) Tangible, which is in the form of the appearance of physical facilities, equipment, employees, and installed materials. Describe the physical form and services to be received by consumers. Examples such as the state of the building, restaurant facilities, restaurant design, and neat appearance of employees;

2) Reliability, namely the ability to provide the promised service reliably and accurately. If seen in the restaurant service business, a reliable service is when an employee is able to provide services as promised and help solve problems faced by consumers quickly; 
3) Responsiveness, which is the willingness to help consumers and provide services quickly. If we look more deeply at the fast response service in a restaurant, it can be seen from the ability of employees who are quick to provide service to consumers and quickly handle their complaints;

4) Assurance, namely knowledge, courtesy, and the ability of employees to generate confidence and trust. A certainty restaurant service becomes important to be provided to consumers, such as guarantees of security and safety in transactions and guaranteed consumer confidentiality;

5) Empathy, namely personal care and attention given to customers. The services provided by employees must be able to show their concern for consumers.

\section{Consumer Satisfaction}

Kotler and Keller [4] state that "Satisfaction is a feeling of pleasure or disappointment someone who appears after comparing the performance (results) of the product thought to the expected performance". According to Tjiptono and Chandra [6], consumer satisfaction is a situation that is shown by consumers when they realize that their needs and desires are as expected and are well met. Meanwhile, according to Bachtiar [7], consumer satisfaction is a positive feeling of consumers associated with products or services during use or after using services or products.

\section{Hypothesis}

H1 : Service Quality (X) consisting of Tangible variable (X1), Reliability (X2), Responsiveness (X3), Guarantee (X4), Empathy (X5) jointly influence the Consumer Satisfaction variable (Y)

H2 : Tangible Variable (X1) affects the Consumer Satisfaction variable (Y)

H3 : Reliability variable (X2) influences the Consumer Satisfaction variable (Y)

H4 : Responsiveness Variable (X3) influences the Consumer Satisfaction variable (Y)

H5 : Assurance Variable (X4) influences the Consumer Satisfaction variable (Y)

H6 : Empathy Variable (X5) influences the Consumer Satisfaction variable (Y)

\section{Method}

This research is an exploratory implant with a quantitative approach [8]. Research was conducted on palm sugar consumers in West Java. There were up to 100 people who were sponded by the collection of data using a questionnaire that was analyzed using multiple linear distributions.

\section{Results and Discussions}

From research conducted and based on data analysis, it can be seen that the variable Physical Evidence (X1), Reliability (X2), Responsiveness (X3), Guarantee (X4), Empathy (X5) jointly influence the Consumer Satisfaction variable (Y). This is indicated by the significance value of $F$ of $0,000(\alpha<0.05)$ so that $\mathrm{H} 0$ is rejected, then the first hypothesis in this study can be accepted, namely the quality of service consisting of (Tangible (X1), Reliability (X2), Responsiveness (X3), Guarantee (X4), Empathy (X5)) influence sig. to customer satisfaction. Based on the adjusted R Square value of 0.778 or $77.8 \%$ which means that $77.8 \%$ of customer satisfaction variables are influenced by independent variables namely physical evidence, reliability, responsiveness, 
assurance, and empathy, while $22.22 \%$ of customer satisfaction variables are influenced by another variable. The results of this study are in accordance with the theory put forward by Tjiptono [2].

Partially the dominant influence on Consumer Satisfaction (Y) is the variable Responsiveness (X3). This is based on the highest regression coefficient of 0.734 and the largest $t$ count of 8.735 and a significance of $0.000<0.05$ while the variable that has the smallest effect on Consumer Satisfaction (Y) is the Reliability variable (X2) with a regression coefficient of 0.219 . The results of this study are in accordance with the theory put forward by Zeithaml, Bitner and Gremler [5] regarding the dimensions of service quality that affect customer satisfaction, one of which is responsiveness. This is consistent with research conducted by Achmad [9] where the Responsibility variable has a dominant influence on Consumer Satisfaction. The discussion of each variable is as follows:

Table 2: Results of Multiple Linear Analysis Analysis

\begin{tabular}{|c|c|c|c|c|c|c|}
\hline \multicolumn{2}{|l|}{ Variable } & \multirow{2}{*}{$\begin{array}{l}\text { Regression } \\
\text { Coefficient }\end{array}$} & \multirow{2}{*}{$\begin{array}{l}t \\
\text { count }\end{array}$} & \multirow[t]{2}{*}{ Beta } & \multirow[t]{2}{*}{ Sig } & \multirow[t]{2}{*}{ Hypotesis } \\
\hline Dependent & Independent & & & & & \\
\hline Kons & & 4,575 & 6,675 & & 0,407 & \\
\hline \multirow[t]{5}{*}{$\mathrm{Y}$} & $\mathrm{X} 1$ & 0,609 & 5,705 & 0,554 & 0,000 & Accept \\
\hline & $\mathrm{X} 2$ & 0,379 & 2,713 & 0,292 & 0,023 & Accept \\
\hline & X3 & 0,734 & 8,735 & 0,675 & 0,000 & Accept \\
\hline & $\mathrm{X} 4$ & 0,643 & 6,033 & 0,521 & 0,000 & Accept \\
\hline & $\mathrm{X} 5$ & 0,557 & 5,929 & 0,495 & 0,000 & Accept \\
\hline \multicolumn{2}{|l|}{$\mathrm{R}$} & 0,872 & & & & \\
\hline \multicolumn{2}{|l|}{ R Square } & 0,778 & & & & \\
\hline \multicolumn{2}{|c|}{ Adjusted R Square } & 0,754 & & & & \\
\hline \multicolumn{2}{|l|}{ F Count } & 187,890 & & & & \\
\hline \multicolumn{2}{|l|}{ Sig } & 0 & & & & \\
\hline \multicolumn{2}{|l|}{$\mathrm{N}$} & 100 & & & & \\
\hline
\end{tabular}

Source: Primer data processed, 2019

\section{Tangible Variable (X1)}

Based on the t test shows that the variable tangible (X1) has a significant effect on Consumer Satisfaction (Y) with a significance level of $0,000<0.05$ so that the second hypothesis $(\mathrm{H} 2)$ in this study is accepted. Variable tangible (X1) includes Toilet Cleanliness, Place Cleanliness, Large Parking Spaces, and Employee Appearance. The results of this study are consistent with the theory put forward by Zeithaml, Bitner and Gremler [5] regarding the dimensions of service quality that affect consumer satisfaction, one of which is physical evidence. This is consistent with the research of Achmad [9], Ermawati [10], Lauw and Kunto [11], and Akbar [12] where tangible variable has a significant influence on the variable of customer satisfaction.

\section{Reliability Variable (X2)}

Based on the t test shows that the Reliability variable (X2) has a significant effect on Consumer Satisfaction (Y) with a significance level of $0.023<0.05$ so that the third hypothesis $(\mathrm{H} 3)$ in this study is accepted. Reliability variable (X2) includes the professionalism of employees in providing services, the suitability of service delivery, and timeliness of service. The results of this study are 
consistent with the theory put forward by Zeithaml, Bitner and Gremler [5] regarding the dimensions of service quality that affect customer satisfaction, one of which is reliability. This is consistent with the research of Achmad [9], Ermawati [10], Lauw and Kunto [11], and Akbar [12] where the reliability variable has a significant influence on the variable of customer satisfaction.

\section{Responsiveness Variable (X3)}

Based on the t test shows that the variable Responsiveness (X3) has a dominant significant effect on Consumer Satisfaction (Y) with a significance level of $0,000<0.05$ so that the fourth hypothesis (H4) in this study was accepted. Variability Responsiveness (X3) includes Speed Professionalism in Providing Services, Response to Complaints. The results of this study are consistent with the theory put forward by Zeithaml, Bitner and Gremler [5] regarding the dimensions of service quality that affect customer satisfaction, one of which is responsiveness. This is consistent with Achmad's research [9] where the responsiveness variable has a significant effect on the variable of customer satisfaction.

\section{Assurance Variable (X4)}

Based on the t test shows that the Assurance variable (X4) has a significant effect on Consumer Satisfaction (Y) with a significance level of $0,000<0.05$ so that the fifth hypothesis (H5) in this study is accepted. Assurance Variables (X4) include Employee Knowledge of Product Variations, Employee Friendliness, and Affordable Employees. The results of this study are consistent with the theory put forward by Zeithaml, Bitner and Gremler [5] regarding the dimensions of service quality that affect customer satisfaction, one of which is guarantee. This is consistent with the research of Achmad [9], Ermawati [10], Lauw and Kunto [11], and Akbar [12] where the assurance variable has a significant influence on the variable of customer satisfaction.

\section{Empathy Variable (X5)}

Based on the t test shows that the Empathy variable (X5) has a significant effect on Consumer Satisfaction (Y). In this study Empathy variable becomes the variable that has a dominant influence on Consumer Satisfaction (Y) with a significance level of $0,000<0.05$ so that the sixth hypothesis (H6) in this study is accepted. Empathy Variable (X5) includes the Willingness of Employees to Help Consumers, Attention Towards Consumer Complaints. The results of this study are consistent with the theory put forward by Zeithaml, Bitner and Gremler [5] regarding the dimensions of service quality that affect consumer satisfaction, one of which is empathy. This is consistent with the research of Achmad [9], Ermawati [10], Lauw and Kunto [11], and Akbar [12] where the empathy variable has a significant influence on the variable of customer satisfaction.

\section{Conclusions}

Based on the results of research conducted to prove the influence together, namely the variable Tangible (X1), Reliability (X2), Responsiveness (X3), Assurance (X4), and Empathy (X5) on Palm Sugar Consumer Satisfaction (Y). This is indicated by the significance of the F count of $0,000<0.05$. The results of this analysis also show that the contribution of Tangible (X1), Reliability (X2), Responsiveness (X3), Assurance (X4), and Empathy (X5) variables is shown from the R square value of 0.778 . This means that the ability of Service Quality variables together to contribute to Consumer Satisfaction is $77.8 \%$ while the remaining $22.22 \%$ is influenced by other variables. 


\section{References}

[1] Supranto, J. 2006. Pengukuran Tingkat Kepuasan Pelanggan Untuk Menaikkan Pangsa Pasar. Jakarta.

[2] Tjiptono, Fandy. 2007. Strategi Pemasaran. Yogyakarta: Andi Offset

[3] Tjiptono, Fandy. 2007. Strategi Pemasaran Edisi kedua. Yogyakarta: Andi Offset.

[4] Kotler, Philip and Kevin Lane Keller. 2009. Marketing management (13th ed.) New Jersey: upper Saddle River.

[5] Zeithaml, V.A., Bitner, M. J. dan Gremler, D. D. (2009). Service Marketing-integrating customer focus across the firm (5th ed.) New York: McGraw-Hill.

[6] Tjiptono, Fandy dan Gregorius Chandra. 2011. Service Quality \& Satisfaction Edisi ketiga. Yogyakarta: Andi Offset.

[7] Bachtiar. (2011). Analisa Faktor-Faktor yang Mempengaruhi Kepuasan Mahasiswa dalam Memilih Politeknik Sawunggalih Aji Purworejo. Dinamika Sosial Ekonomi Vol 7 No. 1.

[8] Supranto, J. 2007. Statistik Untuk Pemimpin Berwawasan Global-Edisi Kedua. Jakarta: Salemba Empat.

[9] Achmad, Fandy. 2007. Pengaruh Kualitas Pelayanan (Service Quality) Dalam Meningkatkan Kepuasan Konsumen (Studi pada Konsumen Rumah Makan Maibu Malang). Skripsi. Fakultas Ilmu Administrasi Universitas Brawijaya Malang.

[10] Ermawati, Wahyu Putri. 2010. Pengaruh Kualitas Pelayanan Terhadap Kepuasan Pelanggan Pada Rumah Makan Saboten Shokudo Malang. Skripsi. Fakultas Ekonomi dan Bisnis Universitas Brawijaya Malang.

[11] Lauw Jessica dan Kunto Sondang Yohanes. 2013. Analisa Pengaruh Kualitas Pelayanan Terhadap Kepuasan Pelanggan di The Light Cup Cafe Surabaya Town Square dan The Square Surabaya. Jurnal. Manajemen Pemasaran Universitas Kristen Petra. Vol.1, No.1.

[12] Akbar, Muhammad. 2016. Pengaruh Kualitas Pelayanan Terhadap Kepuasan Pelanggan (Studi Pada Pengunjung Wisata Kampung Kidz Kota Batu). Skripsi. Fakultas Ekonomi dan Bisnis Universitas Brawijaya Malang. 